\title{
CoLIS’ 10th conference, 2019, in Ljubljana
}

Conceptions of Library and Information Science (CoLIS) is a series of international conferences aiming to provide a broad forum for the exploration and exchange of ideas in the field of Library and Information Science, Information Studies, and related disciplines. It welcomes diverse contributions offering empirical, theoretical and historical perspectives.

The 10th conference in the series will be organized by the Department of Library and Information Science and Book Studies at the Faculty of Arts, University of Ljubljana, and will take place between June 16-19, 2019. Preceding the conference on June 16, 2018, there will be a Doctoral Forum.

The website of the conference is oddelki.ff.uni-lj.si/biblio/colis/, and it also has Facebook and Twitter presence.

The theme of the conference is - as indicated in the name CoLIS - Conceptions (approaches, theories, etc.) of Library and Information Science (LIS). This concerns the well established LIS subfields, such as:

- Knowledge organization

- Knowledge management

- Library studies

- Information architecture

- Information behavior

- Information literacy and related literacies

- Interactive information retrieval

- Information systems

- Scholarly communication

- Bibliometrics, scientometrics, webometrics

- Interaction design and user experience

- Archival studies

- History and philosophy of information

We welcome submissions on all aspects of the subject, including information science, information systems, library science, archives, records management, and digital humanities.

\section{Call for papers}

We invite authors to submit abstracts of research papers for full papers, short papers, panels, workshops, alternative events and posters.

Abstracts of full papers and short papers should be up to 500 words. Once accepted, full papers should be up to 5000 words and short research papers up to 3000 words. 
Full paper abstracts are given priority. All submissions should be in English - the official language of the conference.

All accepted full papers will have the opportunity to be published in the journal Information Research and will be indexed in Web of Science (Social Sciences Citation Index) and other important bibliographical databases.

\section{Doctoral Forum information}

We invite doctoral students to a Doctoral Forum held in connection to the main conference CoLIS 10. The Doctoral Forum will take place on June 16, 2019, at the Faculty of Arts, Ljubljana, Slovenia.

The Doctoral Forum is intended to provide a setting for discussion of doctoral students' research projects with invited senior researchers and other participating students. The discussions will take place in a constructive spirit and a friendly atmosphere, taking into consideration the diversity of contemporary LIS. A further objective is to act as a platform initiating international contacts between doctoral students as well as researchers that may enable future collaboration.

EasyChair submissions for all categories open on December 3, 2018. 